\title{
Pandemic preparedness: doctor leads campaign for UK government to release report
}

\author{
Clare Dyer
}

The BMJ

Lawyers for an NHS doctor are threatening legal action over the government's failure to release an unpublished report on Exercise Cygnus, a 2016 exercise to test the UK's preparedness for a flu pandemic.

Leigh Day, solicitors for Moosa Qureshi, have written a pre-action letter to Matt Hancock, the health and social care secretary for England, demanding that he release the report on Exercise Cygnus. If he does not, the solicitors say, Hancock will face an urgent application for judicial review of the decision not to publish it. The Telegraph has reported that the findings, which followed a three day simulation, were deemed "too terrifying" to be released to the public.

The government, which was asked to reply by 27 April, has asked for further time to respond. But on that day the Sun revealed leaked details from the 57 page report. That report had concluded, the newspaper said, "that the UK's capability to respond to a worst case pandemic influenza should be critically reviewed" and had outlined 22 recommendations on how to improve the government's response to a pandemic.

"Crucially," the Sun reported, "personal protective equipment, ventilators and testing-three key areas where ministers have faced repeated criticism - barely featured or were not part of the exercise."

In a follow-up letter after the Sun report Leigh Day asked the government for a full explanation of how the newspaper had obtained the extracts, confirmation of whether a leak investigation would be carried out, and a full copy of the report.

\section{"No persuasive argument for secrecy"}

Qureshi, who is a campaigner with 54000doctors.org, said, "I am a frontline NHS doctor and I specialise in blood disorders. I provide care for patients with leukaemia who have done particularly badly when infected with covid-19. I have also used a retrovirus during my $\mathrm{PhD}$ research into leukaemia.

"Managing a viral pandemic is completely different from fighting against acts of aggression by military or terrorist organisations. There is no persuasive argument for secrecy when managing a healthcare crisis. Successful science and healthcare provision depend on transparency, peer review, collaboration, and engagement with the public."

Qureshi is funding the legal action by crowd funding on crowdjustice.com and had raised more than $£ 37000$ (€42 300; $\$ 46000)$ by 29 April.

His solicitor, Tessa Gregory, said, "The exercise was carried out precisely in order to anticipate the kind of situation we now find ourselves in. It beggars belief that the information the exercise revealed is now being kept hidden when a public debate about its contents may well inform important decisions about how to best protect lives going forward."

A spokesman for the Department of Health and Social Care said, "We can't comment on proposed or potential legal action." A Freedom of Information Act request by someone else to see the report has already been refused by the government on the grounds that "the release of this information would prohibitively impact the ability of ministers to meet with officials and external stakeholders to discuss ongoing policy development." 